UTILITY: Jurnal IImiah Pendidikan dan Ekonomi

Volume 2, No. 2, Agustus 2018: Page 129-146

ISSN 2549-1377 (Print) || ISSN 2549-1385 (Online)

Available online at http://journal.stkipnurulhuda.ac.id/index.php/utility

\title{
Penggunaan Model Pembelajaran Problem Based Learning (PBL) dengan Laboratorium Pelatihan Usaha untuk Meningkatkan Minat Berwirausaha
}

\author{
(Quasi Eksperimen Pada Siswa Kelas XI Pemasaran SMK PGRI Subang)
}

\author{
Reni Ika Wijayanti ${ }^{1}$, Ade Sobandi ${ }^{2}$, dan Hari Mulyadi ${ }^{3}$ \\ 1,2,3 Fakultas Pendidikan Ekonomi dan Bisis, Universitas Pendidikan Indonesia \\ *E-mail: reniika40@student.upi.edu
}

\begin{abstract}
Abstrak: Penelitian ini merupakan penelitian quasi eksperimen berbentuk kelompok eksperimen dan kontrol pretes-postes, perlakuan model problem based learning dengan laboratorium pelatihan usaha dan model pembelajaran konvensional di kelas XI Pemasaran SMK PGRI Subang. Penelitian ini bertujuan untuk menganalisis perbedaan minat berwirausaha siswa sebelum dan sesudah pembelajaran menggunakan model PBL dengan laboratorium wirausaha. Menganalisis perbedaan minat berwirausaha siswa sebelum dan sesudah pembelajaran menggunakan model pembelajaran konvensional. Menganalisis perbedaan peningkatan minat berwirausaha siswa yang menggunakan model PBL dibandingkan yang menggunakan model pembelajaran konvensional. Instrumen yang digunakan berupa angket dan lembar pengamatan observasi. Kesimpulan yang diperoleh dari penelitian ini adalah (1) terdapat perbedaan yang signifikan pada minat berwirausaha siswa pada saat sebelum dan sesudah pembelajaran menggunakan model pembelajaran PBL dengan laboratorium wirausaha, (2) terdapat perbedaan yang signifikan pada minat berwirausaha siswa pada saat sebelum dan sesudah pembelajaran menggunakan model pembelajaran konvensional. (3) terdapat peningkatan gain rata-rata kelas eksperimen yang lebih besar dibandingkan kelas kontrol.
\end{abstract}

Kata Kunci: minat berwirausaha, pembelajaran kewirausahaan, problem based learning, laboratorium wirausaha, pembelajaran konvensional

UTILITY: Jurnal IImiah Pendidikan dan Ekonomi

Permalink: https://journal.stkipnurulhuda.ac.id/index.php/utility/article/view/353

How to cite (APA): Wijayanti, R., Sobandi, A., \& Mulyadi, H. (2018). Penggunaan Model Pembelajaran Problem Based Learning (PBL) dengan Laboratorium Pelatihan Usaha untuk Meningkatkan Minat Berwirausaha. UTILITY: Jurnal IImiah Pendidikan Dan Ekonomi, 2(2), 129-146.

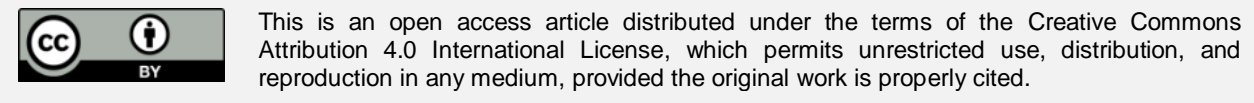




\section{PENDAHULUAN}

Perkembangan dan kemajuan suatu bangsa ditentukan oleh Sumber Daya Manusia (SDM) yang handal, sedangkan SDM tercipta dari hasil proses pendidikan yang berkualitas. Salah satu jenis SDM yang mampu membangun suatu negara adalah seseorang yang memiliki jiwa wirausaha mandiri sehingga mampu mewujudkan peningkatan kesejahteraan diri, masyarakat dan lingkungan (Noyes, 2016). Mengutip pendapat David Mc Clelland seorang ilmuan social-pembangunan yang terkenal dengan konsep Need for Achievement (dalam Ciputra, 2008, hlm.5) bahwa "suatu negara akan maju jika terdapat wirausaha sedikitnya dua persen dari jumlah penduduk".

Data Badan Pusat Statistik (BPS) Indonesia tahun 2017 jumlah pengusaha di Indonesia meningkat yang sebelumnya sebesar 1,67\% menjadi 3,1\% dari jumlah penduduk di Tahun 2017, meskipun jumlah pengusaha di Indonesia meningkat, namun masih dinilai lebih rendah dibandingkan pengusaha di Malaysia yang jumlahnya sebesar 6\% dari total penduduknya. Survei data Global Entrepreneurship Monitor (GEM) pada tahun 2017 Rasio wirausaha di bawah negara tetangga kita, dapat dilihat Negara Singapura 7 persen, Malaysia 6 persen, Thailand 5 persen.

Rendahnya jumlah pengusaha di Indonesia dikarenakan sebagian besar lulusan memilih untuk menjadi seorang pegawai dibandingkan seorang wirausaha yang menciptakan lapangan pekerjaan sendiri. Banyaknya pencari kerja di Indonesia tidak diimbangi dengan banyaknya lapangan pekerjaan yang mengakibatkan banyak orang tidak mendapatkan kesempatan bekerja, akibatnya jumlah pengangguran semakin bertambah yang berdampak pada perekonomian Indonesia. Presentase pengangguran terbuka yang berasal dari lulusan SMK sebesar 20,73\% atau sebanyak 1.424.428 jiwa dengan total jumlah pengangguran sebanyak 6.871.264 jiwa di tahun 2018, yang menunjukkan bahwa jumlah pengangguran di Indonesia masih tinggi (Badan Pusat Statistik, 2018).

Masalah pengangguran yang masih tinggi dapat diperkecil dengan cara berwirausaha. Berwirausaha merupakan cara yang paling tepat untuk mengatasi pengangguran dengan menyerap tenaga kerja. Selain itu, dengan menciptakan lapangan pekerjaan berpeluang menghasilkan pendapatan yang lebih besar

daripada berkarir menjadi karyawan. Berwirausaha juga membantu 
Penggunaan Model Pembelajaran Problem Based Learning (PBL) dengan

Laboratorium Pelatihan Usaha untuk Meningkatkan Minat Berwirausaha

meningkatkan perekonomian suatu Negara karena dpat membuka lapangan pekerjaan.

Wirausaha seakan menjadi harga mati bagi Negara manapun didunia ini yang ingin naik level yang lebih tinggi sebagai Negara maju. Perlunya menciptakan pengusaha di Indonesia agar dapat disebut Negara maju dan agar suatu Negara mampu membangun perekonomian negaranya dengan menetapkan batas 2 persen dari toal jumlah penduduk haruslah pengusaha (David Mc Clelland, dalam Ciputra, 2008, hlm.5)

Direktur Pembinaan SMK Ditjen Manajemen Pendidikan Dasar dan Menengah (Mandikdasmen) Joko Sutrisno jumlah lulusan SMK yang menjadi wirausaha hanya satu hingga dua persen dari 950 ribu lulusan per tahun. Sedangkan menurut data Badan Pusat Statistik (BPS) Lulusan Sekolah Menengah Kejuruan (SMK) yang terjun ke dunia wirausaha masih sangat rendah. Lulusan SMK lebih mampu mengaplikasikan pengetahuan dan keterampilan dalam dunia kerja sampai tahap menciptakan lapangan kerja sendiri sebagai wirausahawan dibandingkan lulusan sekolah menengah lainnya.

Pengembangan kewirausahaan khususnya dalam entrepreneurial intention hingga saat ini masih menjadi isu penting bagi lembaga-lembaga ekonomi mulai dari tingkat daerah, nasional bahkan internasional (Matlay, 2001;Ratsimanetrimanana, 2015). Terdapat jalur pendidikan yang mempersiapkan lulusannya memiliki kesiapan bekerja, khususnya kompetensi dalam berwirausaha yakni sekolah kejuruan.

Banyak pendidik yang kurang memperhatikan penumbuhan sikap, minat, dan perilaku wirausaha peserta didik, baik di Sekolah menengah Kejuruan (SMK) maupun di pendidikan professional (Jones, English, Jones, \& English, 2006; (Cooper, Bottomley, \& Gordon, 2004; (S. R. H. N. L. T. N. Krueger, 2016). Pendidikan kewirausahaan di Indonesia dinilai masih kurang dalam memperoleh perhatian masyarakat. Khususnya oleh para pendidik model pembeljaran yang digunakan masih menggunakan model pemnbelajaran tradisional yakni focus pembelajaran yang masih terpusat pada guru (teacher centered) tidak pada siswa (student centered) (Endang Mulyani, 2014).

Dilihat dari data alumni persebaran/keterserapan lulusan di SMK PGRI Subang sebagai berikut: 
Reni Ika Wijayanti, Ade Sobandi, dan Hari Mulyadi

Tabel 1 Data Keterserapan Lulusan SMK PGRI Subang Tahun 20162017

\begin{tabular}{ccccccc}
\hline \multirow{2}{*}{ No } & \multirow{2}{*}{$\begin{array}{c}\text { Tahun } \\
\text { Akademik }\end{array}$} & Kuliah & Bekerja & Wiraswasta & $\begin{array}{c}\text { Lain- } \\
\text { Lain }\end{array}$ & \multirow{2}{*}{$\begin{array}{c}\text { Lumlah } \\
\text { Lulusan }\end{array}$} \\
\hline 1 & $2015-2016$ & 3 & 234 & 117 & 233 & 587 \\
2 & $2016-2017$ & 10 & 256 & 128 & 247 & 641 \\
\hline \multicolumn{1}{c}{ Sumber: Bursa Kerja Khusus (BKK) SMK PGRI Subang Tahun 2017 }
\end{tabular}

Banyak lulusan yang memilih bekerja sebagai pegawai atau karyawan dibanding melanjutkan kuliah atau berwirausaha karena keterbatasan modal dan keinginan dari lulusan. Sebab mereka menganggap menjadi karyawan adalah pilihan terbaik dibandingkan menjadi wirausaha yang harus menanggung resiko kerugian dari usahanya.

Terdapat teori yang digunakan untuk mengatasi permasalahan dalam peningkatan minat berwirausaha yakni teori Ajzen (1991) yakni Theory of Planned Behavior yang menyatakan bahwa minat merupakan variabel antara yang menyebabkan terjadinya perilaku dari suatu sikap maupun variabel lainnya. Variabel lain yakni pendidikan kewirausahaan dan pelatihan kewirausahaan merupakan usaha dalam meningkatkan minat wirausaha (J. N. F. Krueger \& Carsrud, 1993).

Minat wirausaha dalam Theory of Planned Behavior dibutuhkan pendidikan kewirausahaan, namun pada kenyataannya pendidikan kewirausahaan hanya mampu menuntut siswa untuk menghafal saja. Metode yang sering dipakai dalam pembelajaran adalah ceramah, mencatat, pemberian pekerjaan rumah (PR) dan ulangan yang menuntut siswa untuk menghafal semua materi yang pernah diterima. Guru menyampaikan materi yang banyak dan teoritis sementara siswa hanya mendengarkan, mencatat dan mengerjakan soal yang diberikan guru tanpa adanya aplikasi dari materi yang telah diberikan ke dalam lingkungan sebenarnya.

Menumbuhkan pelaku usaha melalui pendidikan formal telah dilakukan pemerintah sejak dulu, namun pertumbuhan dan perkembangannya dinilai tidak efektif dalam memenuhi ekspektasi bahwasannya pendidikan formal dapat menyelenggarakan pedidikan kewirausahaan. Oleh karena itu, pemerintah mengevaluasi macetnya pendidikan kewirausaan pada pendidikan formal. Melalui Instruksi Presiden No 9 Tahun 2016 tentang Revitalisasi Sekolah 
Penggunaan Model Pembelajaran Problem Based Learning (PBL) dengan

Laboratorium Pelatihan Usaha untuk Meningkatkan Minat Berwirausaha

Menengah Kejuruan (SMK) dalam rangka peningkatan Sumber Daya Manusia (SDM) Indonesia. Pendidikan formal atau SMK berupaya mampu mengubah pola pikir lulusan SMK yang tidak hanya menjadi lulusan siap kerja namun menjadi lulusan siap berwirausaha dan mandiri. SMK tidak berjalan sendiri, pemerintah memberikan dukungan yata dengan adanya link and match SMK dengan DU/DI dan penggemblengan mata pelajaran prakarya dan kewirausahaan.

Guru perlu mengupayakan untuk mengaktifkan siswa, meningkatkan kemampuan berfikir kritis, meningkatkan kepekaan di lingkungan masyarakat dan mengembangkan nalar siswa. Siswa harus dimotivasi untuk berinteraksi dengan lingkungan sehingga siswa dapat membangun pengetahuan terhadap dunia sekitar, membangun kepercayaan diri dan mampu mengaplikasikan ilmu yang diperoleh di sekolah untuk memajukan masyarakat.

Salah satu model pembelajaran yang mampu mengembangkan hal-hal tersebut adalah model Problem Based Learning (PBL) dengan menggunakan media pembelajaran yang mampu membuat siswa aktif diantaranya media Laboratorium pelatihan usaha. Laboratorium merupakan tempat pelatihan usaha siswa Bidang Keahlian Manajemen Bisnis. Laboratorium digunakan untuk kegiatan pengajaran yang memerlukan praktek keterampilan tertentu dan atau pengalaman-pengalaman langsung bagi siswa. Sehingga mampu memberikan pengalaman langsung bagi siswanya.

Penggunaan model pembelajaran problem based learning dengan menggunakan laboratorium dikatakan berhasil jika siswa mampu menunjukkan minat wirausaha dengan memiliki kemampuan pengetahuan, keterampilan, dan sikap (Buchari Alma, 2010:56). Sehingga perlu dilakukakan penelitian mengenai "penggunaan model pembelajaran problem based learning dengan laboratorium pelatihan usaha untuk meningkatkan minat berwirausaha (quasi eksperimen pada siswa kelas XI Pemasaran SMK PGRI Subang)".

Penelitian ini untuk melihat apakah terdapat perbedaan minat berwirausaha siswa sebelum dan sesudah pembelajaran dengan menggunakan model problem based learning dengan laboratorium wirausaha, dan model pembelajaran konvensional. Serta untuk melihat apakah terdapat perbedaan peningkatan minat berwirausaha siswa antara kelas yang menggunakan model problem based learning dengan laboratorium wirausaha dibandingkan kelas yang menggunakan model pembelajaran konvensional. Hasil penelitian ini 
diharapkan dapat menjadi pemicu untuk mengembangkan model pembelajaran yang dapat meningkatkan minat berwirausaha siswa dalam pembelajaran kewirausahaan pada berbagai tingkatan pendidikan.

\section{METODE}

Penelitian ini telah dilaksanakan di kelas XI Pemasaran 2 dan XI pemasaran 3 SMK PGRI Subang. Metode Penelitian ini merupakan jenis penelitian quasi eksperimen. Desain penelitian yang digunakan adalah The randomized pretest-posttest control groups design (Sugiyono, 2011:122). Menggunakan dua kelas yaitu kelas eksperimen dan kelas kontrol, yang diambil secara acak kemudian memberikan tes sebelum perlakuan (pretest) dan sesudah perlakuan (posttest) (Darmadi, 2011:36). Dapat dilihat pada Tabel 2 desain penelitian sebagai berikut:

Tabel 2 Bentuk Kuasi Eksperimen Nonequivalen Control Group Design

\begin{tabular}{|llll|}
\hline Kelompok & & Pretest & \multicolumn{2}{c|}{ Perlakuan } & Posttest \\
\hline Eksperimen (A) & O1 & X & O2 \\
\hline Kontrol (B) & O1 & \multicolumn{2}{c|}{ O2 } \\
\hline
\end{tabular}

Sumber: (Darmadi, 2011:203)

Keterangan:

$\mathrm{X}$ :Perlakuan pembelajaran menggunakan model Problem Based Learning (PBL) dengan Laboratorium pelatihan usaha

O1 : Pretest eksperimen

$\mathrm{O} 2$ : Posttest eksperimen

O1 : Pretest kontrol

O2 : Posttest kontrol

\section{HASIL DAN PEMBAHASAN}

\section{Hasil}

Minat berwirausaha siswa sebelum dan sesudah diberikan perlakuan (eksperimen) diukur dengan menggunakan instrumen tes tertulis berupa angket yang sama. Berikut adalah hasil perhitungan data gain minat berwirausaha siswa: 
Penggunaan Model Pembelajaran Problem Based Learning (PBL) dengan

Laboratorium Pelatihan Usaha untuk Meningkatkan Minat Berwirausaha

Tabel 3 Deskripsi Data Gain Ternormalisasi Peningkatan Minat Berwirausaha Siswa

\begin{tabular}{|c|c|c|c|c|c|c|c|}
\hline \multirow[t]{2}{*}{ Kemampuan } & \multirow[t]{2}{*}{ Statistik } & \multicolumn{3}{|c|}{$\begin{array}{c}\text { Model Problem Based } \\
\text { Learning dengan } \\
\text { Laboratorium Wirausaha } \\
\end{array}$} & \multicolumn{3}{|c|}{$\begin{array}{c}\text { Pembelajaran } \\
\text { Biasa }\end{array}$} \\
\hline & & Pretes & Postes & Gain & Pretes & Postes & Gain \\
\hline \multirow{3}{*}{$\begin{array}{c}\text { Minat } \\
\text { Berwirausaha }\end{array}$} & $\bar{x}$ & 89.57 & 118.08 & 0.49 & 85.48 & 99.2 & 0.22 \\
\hline & $\%$ & 256 & 337 & & 244 & 283 & \\
\hline & $\mathrm{S}$ & 9.03 & 10.05 & 0.20 & 8.02 & 7.52 & 0.14 \\
\hline \multirow{3}{*}{$\begin{array}{c}\text { Model } \\
\text { Pembelajaran PBL }\end{array}$} & $\bar{x}$ & & 69.11 & & & 57.8 & \\
\hline & $\%$ & & 197 & & & 165 & \\
\hline & $\mathrm{S}$ & & 9.41 & & & 4.61 & \\
\hline
\end{tabular}

Sumber: Data Primer diolah

Berdasarkan Tabel 3, dapat dideskripsikan bahwa untuk tes awal (pretest) kelas eksperimen (model pembelajaran problem based learning dengan laboratorium wirausaha) minat berwirausaha siswa memiliki peningkatan gain rata-rata sebesar 0.49 . Sedangkan untuk kelas kontrol (pembelajaran biasa) peningkatan gain rata-rata untuk minat berwirausaha adalah sebesar 0.22. Dapat disimpulkan bahwa minat berwirausaha peningkatan gain rata-rata kelas eksperimen lebih besar dibandingkan kelas kontrol.

Skor rata-rata untuk pembelajaran kewirausahaan yang dilakukan antara kelas eksperimen dan kelas kontrol didapatkan hasil skor paling besar oleh pembelajaran kewirausahaan kelas eksperimen yakni yang menggunakan model pembelajaran problem based learning (PBL) dengan menggunakan laboratorium kewirausahaan dengan perolehan skor rata-rata 69.11. Sedangkan untuk perolehan skor pembelajaran kewirausahaan kelas kontrol yang menggunakan model pembelajaran konvensional lebih kecil dari kelas eksperimen dengan skor rata-rata 57.8, sehingga memiliki selisih rata-rata 11.31 .

Uji respon siswa terhadap model pembelajaran PBL dapat dilihat melalui tabel 4 berikut: 
Reni Ika Wijayanti, Ade Sobandi, dan Hari Mulyadi

Tabel 4 Uji Rerata Respon Siswa Terhadap Model

Pembelajaran

\begin{tabular}{|c|c|c|c|c|c|}
\hline \multicolumn{2}{|c|}{ Kelas } & $\mathrm{N}$ & Mean & Std. Deviation & $\begin{array}{l}\text { Std. Error } \\
\text { Mean }\end{array}$ \\
\hline data_pembelajaran & $\begin{array}{l}\text { Kelas } \\
\text { Eksperimen }\end{array}$ & 35 & 69.1143 & 9.41454 & 1.59135 \\
\hline & Kelas Kontrol & 35 & 57.8000 & 4.61965 & .78086 \\
\hline
\end{tabular}

Sumber: Data Primer diolah

Tabel 4 menunjukkan pembelajaran kewirausahaan kelas eksperimen lebih tinggi dibandingkan kelas kontrol yang menggunakan pembelajaran konvensional. Dengan skor 69.11 di kelas eksperimen dan 57.80 di kelas control.

\section{Uji Hipotesis}

Pengujian hipotesis I menunjukkan hasil uji SPSS 16 melalui teknik Wilcoxon's Matched Paired Test bahwa minat berwirausaha siswa kelas eksperimen dengan nilai sig (2-tailed) 0,000 lebih kecil dari nilai $\alpha=0,05$, artinya Ho ditolak sehingga dapat disimpulkan bahwa terdapat perbedaan minat berwirausaha siswa pada saat pretest dan posttest pada kelas eksperimen.

Pengujian hipotesis II menunjukkan hasil uji SPSS 16 melalui teknik Wilcoxon's Matched Paired Test bahwa minat berwirausaha siswa di kelas kontrol dengan nilai sig (2-tailed) 0,001 lebih kecil dari nilai $\alpha=0,05$, artinya Ho ditolak sehingga dapat disimpulkan bahwa terdapat perbedaan minat berwirausaha siswa pada saat pretest dan posttest pada kelas kontrol.

Pengujian hipotesis III perbedaan posttest minat berwirausaha antara siswa kelas eksperimen dan kelas kontrol dapat dilihat pada data posttest minat berwirausaha. Diketahui bahwa nilai signifikansi kurang dari 0,05 yaitu $0,000<0,05$ berarti Ho ditolak, artinya terdapat perbedaan minat berwirausaha pada siswa kelas eksperimen yang menggunakan model pembelajaran problem based learning (PBL) dengan laboratorium wirausaha, dibandingkan dengan siswa kelas kontrol yang menggunakan model pembelajaran konvensional.

Pengamatan jurnal harian guru dilakukan dengan tujuan untuk mengetahui setiap tanggapan observer mengenai keterlaksaan model pembelajaran problem 
Penggunaan Model Pembelajaran Problem Based Learning (PBL) dengan

Laboratorium Pelatihan Usaha untuk Meningkatkan Minat Berwirausaha

based learning (PBL) pada setiap pertemuan. Diperoleh hasil persentase keterlaksanaan model pembelajaran PBL pada setiap pertemuan bernilai sama. Besar persentase pertemuan 1,2,3, dan 4 adalah $100 \%$ yang berarti langkah pembelajaran yang telah dilakukan oleh guru pada setiap kegiatan telah terlaksana secara sempurna. Sehingga dapat dikatakan bahwa langkah-angkah dalam model pembelajaran telah terlaksana $100 \%$ oleh guru.

\section{Pembahasan}

\section{Model Pembelajaran Berbasis Masalah (Problem Based Learning/PBL) dengan Laboratorium Wirausaha.}

Model pembelajaran pada mata pelajaran kewirausahaan di SMK PGRI Subang sebelum ada perlakuan masih menggunakan model pembelajaran konvensional dengan menggunakan metode ceramah. Dari hasil wawancara terhadap guru mata pelajaran kewirausahaan di SMK PGRI Subang model pembelajaran kewirausahaan yang digunakan masih text-book oriented, hal ini terlihat pada pelaksanaan pembelajaran dengan menggunakan metode ceramah yang divariasikan dengan metode diskusi belum menekankan pada proses berfikir siswa secara mandiri. Sebab pada umumnya diskusi dilakukan pada kelas besar yang masih didominasi guru, materi yang dibahas tidak sesuai dengan kontek dan isu-isu moral yang sedang berkembang dalam masyarakat, terutama yang berhubungan dengan kewirausahaan. Ada kecenderungan siswa hanyalah sebagai pendengar penjelasan guru atau hanya sekedar melengkapi Lembar Kerja Siswa (LKS). Kondisinya menjadi semakin serius, karena pendidik kurang mengembangkan materi pembelajaran nya sesuai dengan kebutuhan siswa. Padahal dengan memperhatikan interest siswa, seorang guru akan dapat mengajar secara efektif.

Setelah diberikan perlakuan dengan menggunakan model pembelajaran berbasis masalah (problem based learning/PBL) di kelas eksperimen, didapatkan hasil penelitian menunjukkan terdapat perbedaan minat berwirausaha siswa sebelum dan setelah diberikan perlakuan. Adanya peningkatan minat berwirausaha siswa kelas eksperimen yang dilihat dari hasil perhitungan rata-rata pretest dan rata-rata posttest. Begitu pula dengan hasil uji hipotesis I didapat hasil bahwa terdapat perbedaam atau peningkatan yang signifikan pada skor minat berwirausaha siswa saat pretest dan posttest pada 
kelas eksperimen yang menggunakan model pembelajaran berbasis masalah (problem based learning/PBL) dengan laboratorium wirausaha.

Hal ini sesuai dengan pendapat pembelajaran (Nurdyansyah \& Eni, 2016; 5-6) Kegiatan belajar mengajar melibatkan beberapa komponen yaitu guru (pendidik), peserta didik, tujuan pembelajaran, isi pembelajaran, metode mengajar, media dan evaluasi. Guru sebagai factor yang perlu mendapatkan perhatian khususnya dalam keterampilan mengajar, mengelola pembelajaran, menggunakan model pembelajaran, media, dan alokasi waktu yang tepat. Model pembelajaran PBL dalam prosesnya guru harus mampu mengorientasi siswa pada masalah dan mengorganisasi siswa. Jika dilihat sebelum adanya perlakuan guru kesuliatan dalam hal mengorientasi dan mengorganisasi siswa dalam mencari sumber dan rekomendasi untuk peningkatan minat berwirausaha. Melalui model PBL siswa dapat lebih aktif dalam proses pembelajaran, dimana sesuai dengan pendapat (Rusman, 2014, hlm 133) mengemukakan bahwa PBL (pembelajaran berbasis masalah) adalah pembelajaran yang melibatkan siswa dalam memecahkan masalah dengan mengintegrasikan berbagai konsep dan keterampilan dari berbagai disiplin ilmu. Didukung juga oleh pendapat (Shoimin, 2014: 132) bahwa siswa didorong untuk memiliki kemampuan memecahkan masalah dalam situasi nyata, siswa memiliki kemampuan membangun pengetahuannya sendiri melalui aktivitas belajar, pembelajaran berfokus pada masalah sehingga materi yang tidak ada hubungannya tidak perlu dipelajari oleh siswa, hal ini mengurangi beban siswa dengan menghafal atau menyimpan informasi, dan siswa terbiasa menggunakan sumber-sumber pengetahuan, baik dari perpustakaan, internet, wawancara, dan observasi.

Penggunaan laboratorium wirausaha juga menunjang proses pembelajaran sesuai dengan pendapat Kozma dkk (Tri Wulaning Purnami, 2016) menyebutkan, laboratorium digunakan untuk kegiatan pengajaran yang memerlukan praktek keterampilan tertentu dan atau pengalaman-pengalaman langsung bagi siswa. Menurut (Emilda Jusmin, 2012, hlm 47) laboratorium merupakan pusat sumber belajar (resources centre/learning resources centre) yang berfungsi melayani berbagai kebutuhan individual suatu fakultas, sekolah atau akademi.

Penggunaan model PBL dengan laboratorium wirausaha mampu meningkatkan minat kewirausahaan siswa, sebab didukung dengan keterlaksanaan model PBL yang dilakukan oleh guru sesuai pengamatan 
Penggunaan Model Pembelajaran Problem Based Learning (PBL) dengan

Laboratorium Pelatihan Usaha untuk Meningkatkan Minat Berwirausaha

observer dilihat dari hasil observasi aktivitas guru di kelas dan respon siswa terhadap model PBL yang telah dilaksanakan. Dimana kegiatan observasi pelaksanaan model PBL disusun berdasarkan langkah-langkah pembelajarannya. Observasi terhadap proses pembelajaran yang dilakukan untuk mengetahui langkah-langkah pembelajran guru selama penggunaan model pembelajaran pada mata pelajaran kewirausahaan untuk meningkatkan minat berwirausaha siswa. Berdasarkan hasil perhitungan, secara umum guru dapat mengimplementasikan model pembelajaran PBL dengan baik. Suasana yang kondusif, dan guru dapat membimbing siswa dalam merumuskan masalah otentik. Persiapan guru mengajar juga dilaksanakan dengan baik. Dilain pihak siswa terlihat antusias dalam mengikuti pembelajaran, apalagi dengan kegiatan praktek langsung yang dilakukan melalui laboratorium wirausaha yang ada di sekolah SMK PGRI Subang. Permasalahan yang diangkat dalam pembelajaran kewirausahaan dalam menemukan peluang usaha dapat meningkatkan keingintahuan sisa dan memacu untuk mempelajari ilmu berwirausaha lainnya, sehingga mampu meningkatkan minat berwirausaha siswa.

Kegiatan diskusi atau dalam penyajian hasil karya siswa mampu melaksanakan dengan baik dengan bimbingan dan pengawasan dari guru. Siswa dan guru mampu mengevaluasi materi yang telah dipelajari pada setiap pertemuannya. Beberapa kendala yang dihadapi dari pengamatan observer yaitu siswa masih belum terbiasa dalam kegiatan praktik penjualan, dimana siswa masih merasa malu jika diperintahkan atau ditugaskan untuk melakukan kegiatan penjualan ke calon konsumen atau konsumen terutama dalam kegiatan pemasaran produk.

Antusias siswa terhadap model pembelajaran PBL dapat dilihat dari hasil perhitungan angket bahwa ketertarikan atau respon positif siswa berada dikategori tinggi. Hal ini sesuai dengan teori Azein 1991 diyakini bahwa faktorfaktor seperti sikap, norma subyektif akan membentuk minat berwirausaha seseorang dan selanjutnya secara langsung akan berpengaruh pada perilaku. Penelitian mengenai minat berwirausaha juga dilakukan oleh Duygu Turker, Senem Sonmez Selcuk (2009) tentang Which factors affect entrepreneurial intention of University students. Hasil survei menunjukkan bahwa pendidikan kewirausahaan dan factor dukungan struktural mempengaruhi minat berwirausaha siswa. Faktor sikap, pendidikan yang dinilai mampu mempengaruhi minat wirausaha juga dikemukakan oleh oleh Cheung, CK; Chan, RYC (2011) tentang The introduction of entrepreneurship education to 
school leavers in a vocational institute menunjukkan bahwa sikap siswa terhadap kewirausahaan dan pendidikan kewirausahaan dapat mempengaruhi minat kewirausahaan. Pendidikan dan pelatihan kewirausahaan dinilai penting untuk menumbuhkan sikap berwirausaha yang nantinya siswa akan memiliki minat berwirausaha.

\section{Model Pembelajaran Konvensional}

Model pembelajaran konvensional di kelas control untuk sebagai pembanding hasil dengan kelas eksperimen yang menggunaka model pembelajaran PBL. Melalui pengujian hipotesis II didapat bahwa terdapat perbedaan atau peningkatan yang signifikan pada skor minat berwirausaha siswa pada saat pretest dan posttest pada kelas kontrol yang menggunakan model pembelajaran konvensional dengan metode ceramah dan diskusi. Model pembelajaran konvensional yang dimaksud secara umum adalah pembelajaran dengan menggunakan metode yang biasa dilakukan oleh guru yaitu memberi materi melalui ceramah, latihan soal kemudian pemberian tugas (Dzamarah, 2010). Pembelajaran pada model pembelajaran konvesional, peserta didik lebih banyak mendengarkan penjelasan guru di depan kelas dan melaksanakan tugas jika guru memberikan latihan soal-soal kepada peserta didik.

Kegiatan yang dilakukan oleh kelas control yakni, pertama guru memberikan pretest kepada siswa untuk melihat kondisi awal minat berwirausaha siswa, lalu guru mengkondisikan siswa untuk mempersiapkan diri dan kelas untuk proses pembelajaran. Guru menyampaikan materi mengenai peluang usaha, memberikan contoh soal terkait dengan materi, pemberian latihan soal, dan memberikan kesempatan kepada siswa untuk berdiskusi atau bertanya jika ada hal yang tidak di mengerti. Pertemuan kedua siswa diberikan materi tentang desain produk, kemudian diberikan contoh soal dan latihan soal yang berasal dari LKS atau buku penunjang. Pertemuan ketiga siswa diberikan materi tentang strategi promosi, diberikan contoh soal dan latihan soal yang terkait. Diakhir pembelajaran siswa diberikan posttest untuk melihat minat berwirausaha siswa dan tanggapan mengenai pembelajaran yang telah berlangsung.

Setelah dilakukan pembelajaran di kelas kontrol diperoleh hasil gambaran respon siswa terhadap model pembelajaran konvensional, bahwa berada pada kategori rendah sebesar $60 \%$ siswa menjawab kurang atau tidak tertarik pada 
Penggunaan Model Pembelajaran Problem Based Learning (PBL) dengan

Laboratorium Pelatihan Usaha untuk Meningkatkan Minat Berwirausaha

model pembelajaran konvensional tersebut. Dalam hal ini dengan model pembelajaran konvensional guru mengalami kesulitan dalam memberikan motivasi kepada siswa agar terlibat dalam proses pembelajaran dan sulit mengorganisasi siswa untuk mencari solusi permalahan atau materi. Hal ini sesuai dengan pendapat (Susanto, 2006, hlm 75-76) bahwa model pembelajaran konvensional dalam prosesnya dinilai berjalan membosankan, peserta didik hanya aktif membuat catatan saja, kepadatan konsep-konsep yang diajarkan dapat berakibat peserta didik tidak mampu menguasai bahan yang diajarkan, pengetahuan yang diperoleh melalui ceramah lebih cepat terlupakan, dan ceramah menyebabkan peserta didik hanya menghafal saja. Model pembelajaran konvensional juga dinilai oleh (Nana Sudjana, 2009, hlm 77) dimana guru mendominasi kegiatan pembelajaran. Sehingga ini kurang menarik perhatian siswa untuk ikut serta dalam kegiatan pembelajaran.

Rendahnya pencapaian peningkatan minat berwirausaha sebeum dan setelah perlakuan ini dikarenakan dalam kegiatan pembelajaran siswa hanya sebagai pendengar sedangkan guru sebagai center nya (teacher centered). Sebaiknya proses pembelajaran guru hanya sebagai fasilitator sedangkan siswa lah yang aktif dalam proses pembelajaran. Sesuai dengan penelitian terdahulu yang dilakukan oleh Collin Jones Jack English (2006) tentang A Contemporary approach to entrepreneurship education, penelitiannya menggambarkan desain dan pengenalan program baru di kewirausahaan di Universitas Tasmania. Dalam hal ini pembelajaran baik dari sisi proses dan tanggung jawab siswa secara efektif dapat dilakukan melalui student centered learning. Penelitian ini menyarankan perlunya pendidikan kewirausahaan yang akan dilakukan di lingkungan belajar. Intinya, gaya mengajar yang berorientasi pada tindakan, mendukung pengalaman belajar, pemecahan masalah, berbasis proyek, kreatif, dan melakukan kegiatan akhir berupa evaluasi dengan guru dan siswa. Kerjasama tim dan motivasi dalam pembelajaran kewirausahaan dinilai penting dan berpengaruh dalam menumbuhkan minat berwirausaha.

\section{Perbandingan Model Problem Based Learning dengan Model Pembelajaran Konvensional.}

Terdapat perbedaan yang signifikan antara model pembelajaran berbasis masalah (problem based learning) dengan laboratorium wirausaha dan model pembelajaran konvensional dalam meningkatkan minat berwirausaha siswa di kelas XI Pemasaran SMK PGRI Subang. Siswa memandang pembelajaran 
dengan model problem based learning dengan laboratorium pelatihan usaha lebih menarik dan membuat peningkatan minat berwirausaha siswa. Dapat dilihat dari hasil observasi selama kegiatan penelitian siswa terlihat antusias dalam melakukan kegiatan pembelajaran, serta siswa dapat menyerap materi dengan lebih baik dibandingkan dengan tidak menggunakan model ini. Siswa lebih senang jika mereka langsung terlibat dalam kegiatan pembelajaran khususnya melalui kegiatan praktek melalui laboratorium wirausaha, dibandingkan jika mereka hanya menerima materi saja dikelas.

Diketahui bahwa dari perhitungan perbandingan peningkatan gain ratarata untuk kelas eksperimen (model pembelajaran problem based learning dengan laboratorium wirausaha) dan kelas kontrol (pembelajaran konvensional) didiapatkan hasil bahwa peningkatan gain rata-rata di kelas eksperimen lebih besar dibandingkan kelas kontrol.

Hasil hipotesis III dengan pengujian rata-rata dua sampel kelas terdapat perbedaan minat berwirausaha pada siswa kelas eksperimen yang menggunakan model pembelajaran problem based learning (PBL) dengan laboratorium wirausaha, dibandingkan dengan siswa kelas kontrol yang menggunakan model pembelajaran konvensional.

Hasil diatas menunjukkan bahwa dengan perlakukan di kelas eksperimen bisa menimbulkan pencapaian dan peningkatan yang berarti. Hal ini sesuai dengan teori Azein 1991 diyakini bahwa faktor-faktor seperti sikap, norma subyektif akan membentuk minat berwirausaha seseorang dan selanjutnya secara langsung akan berpengaruh pada perilaku. Penelitian mengenai minat berwirausaha juga dilakukan oleh Duygu Turker, Senem Sonmez Selcuk (2009) tentang Which factors affect entrepreneurial intention of University students. Hasil survei menunjukkan bahwa pendidikan kewirausahaan dan factor dukungan struktural mempengaruhi minat berwirausaha siswa. Faktor sikap, pendidikan yang dinilai mampu mempengaruhi minat wirausaha juga dikemukakan oleh oleh Cheung, CK; Chan, RYC (2011) tentang The introduction of entrepreneurship education to school leavers in a vocational institute menunjukkan bahwa sikap siswa terhadap kewirausahaan dan pendidikan kewirausahaan dapat mempengaruhi minat kewirausahaan. Pendidikan dan pelatihan kewirausahaan dinilai penting untuk menumbuhkan sikap berwirausaha yang nantinya siswa akan memiliki minat berwirausaha. 
Penggunaan Model Pembelajaran Problem Based Learning (PBL) dengan

Laboratorium Pelatihan Usaha untuk Meningkatkan Minat Berwirausaha

Hasil penelitian sesuai dengan kajian teori dan penelitian yang relevan. Penelitian Ali Dehghanpour Farashah tentang The process of impact of entrepreneurship education and training on entrepreneurship perception and intention Study of educational system of Iran (2013) menunjukkan bahwa pelatihan kewirausahaan meningkatkan minat kewirausahaan seseorang. Minat berwirausaha akan muncul jika dilakukan pendidikan dan pelatihan kewirausahaan, melalui kegiatan tersebut siswa akan berpartisipasi secara langsung dalam kegiatan sehingga akan menumbuhkan minatnya dalam berwirausaha. Hal tersebut dikemukakan juga oleh Kriteria Wald bahwa pendidikan dan pelatihan adalah prediktor signifikan dari minat berwirausaha. Penelitian selanjutnya juga dilakukan oleh Annamária Heuer Lars Kolvereid (2014) tentang Education in entrepreneurship and the Theory of Planned Behaviour Menunjukkan hubungan langsung yang kuat antara partisipasi dalam program pendidikan yang luas di kewirausahaan dan minat bewirausaha. Dengan mengikuti pembelajaran kewirausahaan para siswa dapat mengaktualisasikan sikap dan perilaku wirausaha, menerapkan jiwa kepemimpinan, merencanakan usaha kecil, dan mengelola usaha kecil. Dengan hal tersebut diharapkan dapat menciptakan nilai tambah atau penghasilan, menciptakan lapangan pekerjaan dan berguna bagi orang lain.

Penggunaan model PBL dengan laboratorium wirausaha dinilai efektif meningkatkan antusias siswa belajar sehingga berdampak pada peningkatan minat berwirausaha siswa yang berada pada kategori tinggi. Hal ini sesuai dengan pendapat Bereket Mamo Buli Wasihun Mohammed Yesuf (2015) penelitiannya tentang Determinants of entrepreneurial intentions: Technicalvocational education and training students in Ethiopia, hasil temuannya menunjukkan untuk menumbuhkan minat berwirausaha perlu adanya praktik pendidikan kewirausahaan dengan menyertakan pembelajaran dalam pengambilan keputusan, efektif komunikasi, negosiasi kewirausahaan, kepemimpinan, penggunaan efektif dan efisien sumber, baru pengembangan produk, kreativitas dan berpikir kritis, dan layanan berbasis dan inovasi teknologi

Hasil penelitian tanggapan siswa juga bisa dilihat melalui skor rata-rata untuk pembelajaran kewirausahaan yang dilakukan antara kelas eksperimen dan kelas kontrol didapatkan hasil skor paling besar oleh pembelajaran kewirausahaan kelas eksperimen yakni yang menggunakan model pembelajaran problem based learning (PBL) dengan menggunakan laboratorium 
kewirausahaan. Menurut pengakuan siswa mereka menganggap dengan pembelajaran menggunakan PBL dan laboratorium wirausaha merupakan hal yang baru dan juga mmebuat mereka bersemangat mengikutinya. Sehingga berdasarkan penelitian dapat disimpulkan penggunaan model pembelajaran PBL dengan laboratorium wirausaha siswa dapat meningkatkan minat berwirausaha siswa.

\section{SIMPULAN}

Berdasarkan pembahasan dapat disimpulkan bahwa penggunaan model pembelajaran PBL dengan laboratorium wirausaha dapat meningkatkan minat berwirausaha siswa. Serta terdapat perbedaan minat berwirausaha pada siswa kelas eksperimen yang menggunakan model pembelajaran problem based learning (PBL) dengan laboratorium wirausaha, dibandingkan dengan siswa kelas kontrol yang menggunakan model pembelajaran konvensional. Hal ini dapat juga dilihat bahwa untuk kelas eksperimen (model pembelajaran problem based learning dengan laboratorium wirausaha) minat berwirausaha siswa yang memiliki peningkatan gain rata-rata sebesar 0.49. Sedangkan untuk kelas kontrol (pembelajaran biasa) peningkatan gain rata-rata untuk minat berwirausaha adalah sebesar 0.22 , sehingga peningkatan gain rata-rata kelas eksperimen lebih besar dibandingkan kelas kontrol.

Setelah dilakukan penelitian sebaiknya guru untuk mampu menggunakan model pembelajaran lebih aktif khususnya model pembelajaran problem based learning (PBL) dengan mengorientasi dan mengorganisasi siswa untuk membantu siswa dalam mendefinisikan dan mengorganisasikan tugas belajar yang berhubungan dengan masalah tersebut. Diharapkan dalam penelitian selanjutnya dapat ditemukan faktor-faktor lain yang dapat mempengaruhi minat berwirausaha siswa serta ditemukan model pembelajaran lainnya yang mampu meningkatkan minat berwirausaha siswa khususnya lulusan nanti yang memiliki keinginan untuk menjadi seorang wirausaha.

\section{REFERENSI}

Buchari Alma. (2010). Kewirausahaan (keenambela). Bandung: ALFABETA.

Ciputra, D. I. (2008). Entrepreneurship Mengubah Masa Depan Bangsa (3rd 
Penggunaan Model Pembelajaran Problem Based Learning (PBL) dengan Laboratorium Pelatihan Usaha untuk Meningkatkan Minat Berwirausaha

ed.). Jakarta: Gramedia.

Cooper, S., Bottomley, C., \& Gordon, J. (2004). Stepping out of the classroom and up the ladder of learning An experiential learning approach to entrepreneurship education. Industry \& Higher Education, 1, 11-22.

Darmadi, H. (2011). Metode Penelitian Pendidikan. Bandung: ALFABETA.

Dzamarah, S. B. (2010). Strategi Belajar Mengajar. Jakarta: PT. Rineka Cipta.

Emilda Jusmin. (2012). Pengaruh latar belakang keluarga, kegiatan praktik di unit produksi sekolah, dan pelaksanaan pembelajaran kewirausahaan terhadap kesiapan berwirausaha siswa smk di kabupaten tanah bumbu. Jurnal Pendidikan Teknologi Dan Kejuruan, 21(1), 46-59.

Endang Mulyani. (2014). DEVELOPING AN ENTERPRENEURSHIP EDUCATION PROJECT-BASED. Education + Training, 1, 50-61.

Jones, C., English, J., Jones, C., \& English, J. (2006). A contemporary approach to entrepreneurship education. Education + Training, 46(8/9), 416-423. https://doi.org/10.1108/00400910410569533

Krueger, J. N. F., \& Carsrud, A. L. (1993). Entrepreneurship \& Regional Development: An International Entrepreneurial intentions : Applying the theory of planned behaviour. Entrepreneurship \& Regional Development, $5,315-330$.

Krueger, S. R. H. N. L. T. N. (2016). from teacher-led to student-centered learning. Education + Training, 58(7/8).

Matlay, H. (2001). Entrepreneurial and vocational education and training in central and Eastern Europe, 43(8), 395-404.

Mcclelland, D. (1965). TOWARD A THEORY OF MOTIVE ACQUISITION 1 DAVID c. MCCLELLAND. Motive Acquisition. 
Nana Sudjana. (2009). Penilaian Hasil Proses Belajar Mengajar. Bandung: PT.Remaja Rosdakarya.

Noyes, R. M. E. (2016). "Survey of experiential entrepreneurship education offerings among tp undergraduate entrepreneurship programs." Education + Training, 58(2), 164-178.

Nurdyansyah, \& Eni, F. (2016). Inovasi Model Pembelajaran. Inovasi Model Pembelajaran. NIzamial Learning Center.

Ratsimanetrimanana, B. U. F. A. (2015). Journal of Entrepreneurship in Emerging Economies Culture and entrepreneurial intentions of Madagascan ethnic groups Article information: Journal Of Entrepreneurhip in Emrging Economies, 7(2), 86-114.

Rusman. (2014). Model-model Pembelajaran Mengembangkan Profesionalisme Guru. Jakarta: Raja Grafindo Persada.

Shoimin. (2014). Model Pembelajaran Problem Based Learning, 130.

Sugiyono. (2011). Metode Penelitian Kombinasi (Mixed Methods). (Sutopo, Ed.) (1st ed.). Bandung: ALFABETA.

Susanto, D. (2006). Optimalisasi Pembelajaran Konvensional dengan Model Kontekstual. Jurnal Limit -Matematika ISSN 1858-4527, April 2006(No 2), 66-80.

Tri Wulaning Purnami. (2016). PENGARUH PRESTASI BELAJAR MATA PELAJARAN PRODUKTIF DAN EFEKTIVITAS LABORATORIUM PELATIHAN USAHA TERHADAP MINAT WIRAUSAHA SISWA Tri. Jurnal Ekonomi Pendidikan Dan Kewirausahaan, 4(1), 42-58. 